\title{
KIVÁNDORLÁS ÉS \\ SZABÁLYOZÁSA KÍNÁBAN
}

\section{Koudela Pál}

\section{ÖSSZEFOGLALÓ}

Az 1980-as évektől Kína lehetővé tette, hogy a lakosság egy szűkebb csoportja legálisan is elhagyhassa az országot. A kivándorlás akkor szoros irányítás alatt állt és gazdasági célokat szolgált. Korlátozás a Csing dinasztia kora óta jelen van, azonban az utóbbi két évtizedben egyre kevesebb formális elem gátolja a kiutazást és a kinntartózkodást, s a vezetés egyre rugalmasabban gondolkodik a kivándorlók gazdasági hasznáról; már nem csupán a szellemi tőke behozatalát, a közvetlen hazai befektetéseket, hanem a globális hálózat építését is szem előtt tartva. A kivándorlás Kínából mégis szerény, s a magas társadalmi státuszú csoportokra jellemző. Az elvándorlás nagyságát a befektetői csoportok és a diákság szerepének növekedése határozza meg. Ennek okai a hazai gazdaság bővülésében és a befogadó országok korlátozásaiban kereshetők. A diákság kivándorlásának kezdetét a „reform és nyitás” politikája jelentette, a kormány kifejezetten a szellemi tőke felhalmozását támogatta. Kínában különösen értékes a külföldön megszerzett diploma, noha a felsőoktatás fejlesztése elvben megoldotta az utánpótlást. A tanulási szándékkal kivándorlók jelentős hányada azonban ma sem tér vissza Kínába. A szakképzetlen vagy alacsonyan képzett fizikai dolgozók kivándorlását szorosan ellenőrzi a kormányzat, annak iránya és feltételrendszere a külföldi befektetések változásait követi. Mára ugyanakkor jelentős liberalizáció zajlott le ezen a területen is.

Tárgyszavak: kivándorlás, kivándorlásszabályozás, Kínai Népköztársaság, politikai fejlődés

Koudela Pál, Kodolányi János Egyetem

Email:pkoudela@yahoo.com 


\section{BEVEZETÉS}

Szinte toposszá vált hétköznapi gondolkodásunkban - különösen nyugati, európai, s talán magyar szemmel is -, hogy a bevándorlókat Kínával kapcsoljuk össze. Ez a képzettársítás még az elmúlt évek történéseinek fényében sem halványult el, s részben érthető is, ha az elmúlt évtizedek, illetve világszerte az elmúlt évszázadok bevándorló csoportjainak összetételére gondolunk. A modern nyugati világ számára az első nagyszámú, igazán eltérő kultúrájú közösségeket a kínaiak jelentették, amelyre sokszor szélsőséges politikai reakcióval válaszoltak a kormányok; talán mind között a legismertebb az 1882-es amerikai Chinese Exclusion Act volt. Ha a kivándorlókat az országukat egy évnél hosszabb időre elhagyókkal azonosítjuk, akkor tulajdonképpen ez kibocsátó oldalról is alátámasztható, ennek egyszerủ oka azonban a Kínai Népköztársaság népességének hatalmas méretében kereshető.

Fontos látnunk azonban, hogy Kína szemszögéből nézve a kivándorlás korántsem olyan képet mutat, mint amilyent a bevándorlási oldalról tapasztaltak alapján feltételezhetnénk. Az elmúlt kétszáz év legnagyobb részében az állami politikák jobbára tiltották, korlátozták a kivándorlást, s az ma is elenyésző a népesség méretéhez viszonyítva. Különösen fontos a kivándorlók összetételét is figyelembe venni, hiszen az évszázados nyugati kép, amely a kínai bevándorlókat fizikai munkásokra redukálta, mára egészen más arcot mutat. Ráadásul a kínai kivándorlás az alacsony képzettségủ szegmensben gyors változásokon ment keresztül az elmúlt évtizedekben, és megy ma is. Az 1978 utáni segédmunkát az Öböl-országokban később felváltották a délkelet-ázsiai országok piacai, majd a fejlett kelet-ázsiai országok, és a növekvő kínai beruházások keltette munkaerő-kereslet Afrika országaiban. Ha a kivándorlókat a bevándorlói oldalról határozzuk meg, és az egyes országokban élő, Kínában születettek számát vesszük alapul, akkor 1990-ben a 4,2 millió külföldön élő kínai közül a fele más kelet-ázsiai országban (Hongkongban 1,66 millió) és 634 ezer Délkelet-Ázsiában élt. Számuk a világban 2017-re 9,96 millióra duzzadt, amelynek fele Kelet-Ázsia országaiban, negyede Hongkongban él,' Délkelet-Ázsiában pedig 717 ezer főt számlálnak (UN 2017).

Ebben a tanulmányban a Kínai Népköztársaságból elvándorló népességgel és a kivándorlásra irányuló szabályozásokkal foglalkozunk. A kivándorlás elsősorban demográfiai folyamat, illetve a kivándorlók strukturális elemzése demo-

\footnotetext{
${ }^{1}$ A Kinában született Hongkongban élőket a kínai adminisztráció statisztikai adatként és jogszabályi kontextusban is kivándorlóként kezeli. Ezt Hongkong sajátos autonómiája és az önálló jogrendszere indokolja.
} 
gráfiai helyzetet ír le. Az írás másik felében a kivándorlásra vonatkozó kormánypolitikákat mutatjuk be, ami elsősorban a népesedés, pontosabban a migrációs politika egyes összetevőit jelenti. A két rész tehát elkülönül egymástól, részben demográfiai, részben társadalompolitikai elemzésről lévén szó, ugyanakkor igyekszünk mindvégig a kölcsönös összefüggések feltárásával szorosabbra fonni az eltérő tartalmakat. A tanulmány fő célja éppen annak kimutatása, hogy a gazdasági-társadalmi változások, valamint a népesedéspolitikai szabályozás miIyen kölcsönhatásban van a kivándorlással Kínában. Ezt elsősorban már meglévő elemzések összefoglalásával érjük el, ám ahol lehetséges és indokolt, az elsődleges forrásokat is felsorakoztatjuk, így nagy nemzetközi szervezetek népesedési adatait és jogszabályokat.

Ki kell hangsúlyozni a különbséget a kínai diaszpóra és a kínai kivándorlók állománya között. Habár az évente el- és visszavándorlók, valamint a külföldön élők állománya között dinamikus kapcsolat áll fenn, a tartós munkavállalás és a letelepedés közötti viszonyrendszer sokrétű, így pl. jelentős a továbbvándorlás is (különösen Délkelet-Ázsiából a nyugati országokba), amely elsősorban a befogadó országok integrációs, letelepedési és állampolgársági politikáinak és a gazdasági feltételek változásának köszönhető. Ennél jóval nagyobb szakadék húzódik azonban a kínai diaszpóra és a külföldön élő, sőt még a tartósan letelepedő (akár állampolgárságot nyert) kínaiak között. A kinai diaszpórára irányuló hazai állami politikák ugyanis jóval átfogóbb képpel rendelkeznek, s alapjaiban egyfajta kulturális identitásra építő gazdaságpolitikai koncepciót rejtenek. Ennek része, hogy a kínai diaszpórába mindenkit integrálni igyekeznek, akinek bármilyen kevés kapcsolata van hajdani származási országával, legyen az másod-, harmad- vagy akárhányadik generációs bevándorló. Erről a jelenségről sem népmozgalmi, sem a rá irányuló politikák értelmében itt nem szándékozunk beszélni.

A kivándorlás kérdése a Népköztársaságban tehát egyfelől nem olyan jelentős probléma, mint azon országokban, ahol az elvándorlók száma, s különösen kor és végzettségi összetétele, már gazdasági krízissel fenyeget. Másfelől a nyolcvanas évek elejétől, a „,reform és nyitás” politikájával megjelenő értelmiségi kivándorlás még ma is komoly veszteséget jelent az országnak, akkor is, ha a felsőoktatás expanziója és minőségi javulása részben meg is oldotta az utánpótlást. A külföldön tanulás értéke, a külföldi tapasztalat hazavitele azonban fokozatosan elveszíti korábbi stratégiai jelentőségét (noha az egyes személyek számára továbbra is kiugró előnyt jelent), egyszerűen azért, mert a külföldön tanuló kínai diákok egyre nagyobb, de még mindig csak egy része tér haza, s ezt az elmúlt évtizedekben, sem sikerült teljesen megváltoztatni. Ezen a ponton 
kapcsolódik az átfogó „nemzettest” stratégiájába a kivándorlók kezelése - s csak részben a diákság kérdéseként, sokkal inkább általános emigrációs stratégiaként -, s törekszik inkább a kivándorlók későbbi életpályaszakaszban történő gazdasági integrációjára, mint hazacsábításukra.

A legfontosabb változás a kivándorlás szabályozása terén Kínában mégis a korábban, 1986-ig domináló védelempolitikai és ideológiai jelleg átalakulása egyfajta utilitarista gazdasági szemléletté. A kivándorlókat már nem korlátozni, hanem támogatni igyekszik a szabályozás egyre egyszerűsödő rendszere, s főképpen gazdasági hasznot remél tőlük. Ez a haszon lehet közvetlen hazautalás vagy a kereskedelmi kapcsolatok bővitéséből származó közvetett előny, a rá irányuló stratégia pedig a korábban kivándorolt diákság hazacsábítása s a diaszpóra hazai befektetéseinek ösztönzése felöl egyre inkább egy nemzetközi kapcsolatháló kiépitése felé tolódik el.

Pontositanunk kell azt is, hogy kik is tartoznak a diaszpórába és ehhez képest mit jelent a kivándorlók csoportja (Charney et al. 2003, Yong 2014, Christiansen 2003, Freedman 2000, Kenley 2003, Kuah-Pearce - Davidson 2008, Lim 2013, Rae - Witzel 2008, Lever-Tracy et al. 1996). Áthatja a politikai diskurzust a sinocentrikus, pontosabban a han-centrikus szemlélet (Barabantseva 2012: 78), a Kínához tartozó területeken élő nemzetiségeket mégsem tekintjük idetartozónak, akkor sem, ha bármilyen más szempont mégis a többségi társadalomtól való különválasztásukat indokolná, vagy ha a kínai politika másként kezeli is őket. Ugyancsak nem tekinthető a diaszpóra részének Makaó, Hongkong, sőt Tajvan lakossága sem. Az előbbi kettő 1997, illetve 1999 óta Kína része; Tajvan ugyanakkor önálló államként definiálja magát, az ENSZ és ami fontosabb, Kína ezt nem ismeri el. Ez a Népköztársaság azon politikájára vonatkozó szempont, amely a tengeren túlon élő kínaiakat hivatott kezelni, és amely nem sorolja közéjük az előbbi lakosokat, odasorol viszont mindenkit, aki nem él az előbbi területeken, viszont akár a legkisebb mértékben is kötődik származásához (Barabantseva 2005: 1). Ez tehát magának Kínának az egy ország, két rendszer -, vagy mára leginkább az egy ország sok rendszer - irányelvéből következik (Zhu 2012).

A diaszpóra szó általánosan használt kifejezéssé vált bármely államalkotó nemzet más országokban élő közösségeire. A kifejezés azonban többet takar, itt a „külföldön élő kínaiak” helyett általában az előbbi kifejezést állítjuk a középpontba, és még akkor is a kibővített értelmet tulajdonítjuk neki, ha időnként a külföldi, külföldön élő vagy az emigráns kifejezéseket alkalmazzuk. Azzal ellentétben ugyanis nem csupán a Kínában született, de külföldön élő népességet 
fedi le, hanem azokat is, akik születés vagy származás révén tartják magukat kínainak (Brubaker 2005: 5). Erre különös okunk van, ugyanis a kínai diaszpóra olyan közösségeket képez, amelyeknek viszonya az anyaországgal egyedi, a kapcsolat különlegessége a sokadik generációkban is érvényesül, és amelyre a Népköztársaságban konkrét migrációs politika is irányul. Ennek megfelelően, a kivándorlás és a kivándorlók mint dinamikus és statikus adat is a Kínában született és a nem Kínában élő népességre vonatkozik. A kínai diaszpórával részletesen foglalkoztam másutt (Koudela 2017).

A fenti értelmezés azonban egy jelentős nehézséggel is küzd, és ez magának a diaszpórának a számszerűsítése. Éppen a kötődés megléte és a származás/ örökség feltételezése között húzódik a leghomályosabb vonal, habár rengeteg becslés lát napvilágot, főként a sajtóban (Reforms urged), de akár szakértői elemzésekben is, akik sokszor szintén a sajtót veszik alapul (Liu - Du 2014, Wang 2012: 1). Ezek a források 50 millióra, míg Barabantseva (2005: 1) 30 millióra becsüli a kínai diaszpóra számát. A legtöbb elemzés mögött azonban nem áll sem forrás, sem módszertani értelmezés, így hitelességük kérdéses. Ráadásul nem állnak rendelkezésre egyszerű statisztikák, amiket a fogadó országok bevándorlási hivatalai, népszámlálásai rögzítenek születési vagy utolsó tartózkodási hely szerint. Ilyen tágan értelmezve pl. a legnagyobb diaszpóra a világon még csak nem is az indiai vagy kínai, hanem a német, amelynek nagyságrendjét Dudley Poston 95 millióra teszi. Az ő értelmezésében a kínai diaszpóra nagyságára nézve csupán a harmadik helyen áll az írek mögött, 40,3 millió fővel (Poston - Wong 2014: 27). Míg azonban a két legnagyobb diaszpóra csupán a 18. századtól eredeztethető, a kínai kétezer éves múltra tekint vissza.

\section{A KÍNAI KIVÁNDORLÁS FORMÁl ÉS CÉLTERÜLETEI}

A Kínából történő kivándorlás időszakait, összetételét, illetve típusait tekintve sokféleképpen osztályozható, ám alapvetően egy 1949 előtti nagymértékű, képzetlen munkaerő-elvándorlást, valamint a kommunista Kína megszületésével egy kismértékü, majd 1978 után egy újra gyarapodó, főként képzett kivándorlókból álló emigrációt különíthetünk el egymástól. Az elmúlt évtizedekben ismét szemtanúi lehettünk annak, hogy a kivándorlást mozgató erők mekkora feszültséget okoznak a Népköztársaságban, ennek következtében folyamatosan nőtt is a kivándorlók száma, olyannyira, hogy mára Kína a negyedik legnagyobb kibocsátó ország, az összes emigráció 4\%-át adja. 
KOUDELA PÁL

1. táblázat: A külföldön élő kinaiak száma

Number of Chinese residents living abroad

$\begin{array}{cccccc}1990 & 1995 & 2000 & 2005 & 2010 & 2015 \\ 4227807 & 4901412 & 5753739 & 7192592 & 8598028 & 9546065\end{array}$

Forrás: UN 2015b.

Mindez azonban máris csekélynek bizonyul, ha az ország közel 1,4 milliárdos népességéhez viszonyítjuk, ami viszont a föld 7,349 milliárdos népességének 20\%-a volt 2015-ben (UN 2015a: 1). Ugyancsak alacsony a nettó migrációs ráta Kínában, gyakorlatilag évtizedek óta valamivel nulla alatt mozog.

2. táblázat: Kina ezer före jutó nettó migrációs rátája és annak elörejelzése, 1985-2020 Net migration rates and predictions in China, 1985-2020

$\begin{array}{ccccccc}1985-1990 & 1990-1995 & 1995-2000 & 2000-2005 & 2005-2010 & 2010-2015 & 2015-2020 \\ 0,0 & -0,1 & -0,1 & -0,4 & -0,3 & -0,2 & -0,2\end{array}$

Forrás: Asian Development Bank Institute 2014: 55.

2015-ben ez az érték -0,4 volt, amivel Kína a 121. helyen, az országok közötti rangsorban valahol a középmezőnyben helyezkedik el (CIA World Factbook). A kivándorlás növekedése egyben annak kettészakadásával is együtt járt. A magasan képzettek kivándorlási aránya ugyanis ötszöröse a képzetlenekének. Ez a jelenség kifejezetten az elmaradott országokra jellemző, mint pl. az afrikai államok, ezzel szemben akár Európában, akár Észak-Amerikában nincs jelentős különbség a magasabb iskolai végzettségüek kivándorlási aránya és a teljes migrációs ráta között (Clemens 2013, Docquier 2014). Valamelyest ugyancsak nőtt a kivándorlás Kínából a fejlettebb országokba - a legfontosabb célpontok Ausztrália, Új-Zéland, Japán és Európa, valamint Észak-Amerika országai -, de aránya a teljes kivándorlásban továbbra is csak valamivel 50\% fölött van.

Mindennek hátterében részben a belföldi és a fogadó országok vízumpolitikájának változása áll, de a kínai diaszpórapolitikáról elmondható, hogy a külföldön élő kínaiakkal kapcsolatban a megváltozott nemzetstratégia nem fél az elvándorlás okozta demográfiai és gazdasági veszteségektől, így nem gátolja, hanem időnként még serkenti is azt. Ez nem azt jelenti, hogy ne hallhatnánk a kínai médiában indulatos kirohanásokat a kivándorlókkal szemben. (者徐哲 2019, 非洲裔人员聚集事件调查) Az, hogy a tőke elhagyja az országot, 
sokakból félelmet kelt, és persze vitát indukál (Xiang 2014). Megvan az oka a szellemi tőke elvándorlásától való félelemnek is, nem volt még olyan régen, amikor a nyugati országok brain drain-je érzékelhetően negatív hatással volt az országra. 1978 után történt, amikor a hazai felsőoktatás még nem tudta pótolni a frissen megengedett, hirtelen megindult értelmiségi kivándorlás okozta hiányt, és még messze volt a reménye is annak, hogy a visszavándorlás meginduljon. Az irányítás logikus elképzelése a tőkekivitel hasznáról (Shu-Ching 2008) és annak hatásáról a kereskedelemre (Liu et al. 2015) ugyan ellentmond ennek a félelemnek, de nem szünteti meg a közhangulat hullámzását: hol támogatja a kereskedelem élénkitését, hol félti az országot a humántőke-veszteségtől. A kormány által is befolyásolt média sokszor használja fel a személyek kivándorlásának és a tőke kimentésének összekapcsolását a közhangulat befolyásolására - noha az is igaz, hogy a kettő teljesen nem is elválasztható egymástól.

Ezzel szemben az alacsony végzettségűek kivándorlását nagyon is szigorúan ellenőrzi a Népköztársaság. Azonban a másik oldalról nézve, a magasan kvalifikált kínaiak beutazását szinte minden nyugati országban vízumkényszer korlátozza. A gyakori határátlépésre kényszerülő üzletemberek, tudósok és más szakemberek így gyakran csupán azért választják a letelepedéssel járó bevándorlást valamely fejlett országba, hogy ezt a nehézséget kiküszöböljék (Miao - Wang 2017: 5).

3. táblázat: A 15 éves és annál idősebb, Kinából és néhány más területről származó kivándorló népesség az OECD országokban, születési hely szerint, 2010/2011-ben

Emigrant population 15+ in the OECD in 2010/11 by country and region of birth

$\begin{array}{lcccc}\begin{array}{c}\text { Származási ország } \\ \text { vagy terület }\end{array} & \begin{array}{c}\text { Kivándorló } \\ \text { népesség, ezer }\end{array} & \begin{array}{c}\text { Magas végzettségü } \\ \text { kivándorló } \\ \text { népesség }\end{array} & \text { Migrációs arány } & \begin{array}{c}\text { Magas } \\ \text { végzettségüek } \\ \text { migrációs aránya }\end{array} \\ \text { Kína } & 3862 & 1655 & 0,4 & 1,8 \\ \text { Európa } & 32759 & 9270 & 5,0 & 5,3 \\ \text { Észak-Amerika } & 2406 & 1164 & 0,9 & 0,8 \\ \text { Afrika } & 10490 & 2865 & 2,4 & 10,8\end{array}$

Forrás: OECD 2013.

\section{A befektetői vízumok kérdése}

A legfontosabb változás a kínai emigrációban a befektető kivándorlók egyre nagyobb számú megjelenése. Olyan tehetős emberekről van szó, akik annak 
fejében kapnak állandó tartózkodási vagy letelepülési engedélyt, hogy beruháznak egy adott összeget a befogadó ország gazdaságába. A befogadó oldalról nézve ez a bevándorláspolitika nem ritka. Számtalan ország kínál befektetői vízumot, és kéri érte egy adott összeg beruházását az ingatlanpiacba, kormánykötvényekbe vagy alacsony kamatozású, sőt időnként kamat nélküli kötvényekbe. Néhány esetben nem is a befektetés, hanem a vissza nem térítendő hozzájárulás a feltétel, és az is változó, hogy állandó letelepedést vagy akár azonnali állampolgárságot ad cserébe az adott ország. Általában fejlett gazdaságok alkalmaznak ilyen vízumpolitikát, mint pl. a csendes-óceáni térségben Ausztrália, Új-Zéland, Japán, Dél-Korea és Kanada, illetve Európában Belgium, Franciaország, Németország, Hollandia, Portugália, Spanyolország, Svájc és az Egyesült Királyság, de kínál ilyen programot Bulgária és a karibi Dominikai Köztársaság, valamint Saint Kitts és Nevis is. Ez utóbbi ráadásul mindössze 400 ezer dollár ingatlanberuházást kér, és viszonzásul teljes értékủ állampolgárságot kínál, amely vízummentes utazást tesz lehetővé Európába, az Egyesült Királyságba és a Nemzetközösség legtöbb országába. Az eljárás ráadásul csupán hat hónapig tart, ennek során nem kérnek a jelentkezőtől állandó tartózkodást, vagy egy egyszerủ odautazást sem. A program 2012 óta azt is lehetővé teszi, hogy 250 ezer dollár, a Cukoripari Diverzifikációs Alapnak tett adomány esetén igényeljék a szóban forgó vízumot (St Kitts \& Nevis). Habár a karibi ország kormánya korlátozza a kiadható vízumok számát, 2013-ban már 10 ezer kínai kérelem várt elbírálásra (Cole 2013).

A legtöbb esetben tehát nem csupán arról van szó, hogy egy adott összeghatárt el kell érnie a befektetésnek, hanem az is meghatározott, hogy milyen fejlesztési területen és mennyi munkahelyet kell teremtenie a beruházásnak. Az Egyesült Államok EB-5 típusú vízuma pl. nem határozza meg a szektort, viszont a földrajzi fekvésétől függően elmaradott térségekben 500 ezer, másutt viszont legalább 1 millió dollár összeget ír elő, valamint azt, hogy legalább tíz állandó, teljes állású munkahelyet teremtsen vagy őrizzen meg a beruházás (U.S. Department of Homeland Security).

Az utóbbi években a legtöbb ilyen befektetői vízumigénylés a fejlett országokba éppen kínai kivándorlók részéről érkezett, és erre a drasztikus változásra reagáltak is a kormányok. Kanada 1986-ban vezette be befektetői vízumprogramját, így csupán 800 ezer kanadai dollár garantált kormánykötvénybe történő befektetését, valamint 1,6 milliónyi tulajdoni értéket kért (Canadian Citizenship). Az első jelentősebb bevándorlási hullám 1989-ben érte el az észak-amerikai országot, amikor a Tiananmen téri vérengzés után 30 ezer hongkongi menekült Kanadába. 2010-ben az összes befektetői bevándorló 58\%-a kínai (6817 fö), 8\%-a tajvani (925 fő) volt Kanadában (Citizenship and 
Immigration Canada 2012: 4). 2014-ig összesen 185 ezer bevándorló kapott befektetői vízumot, köztük 67 ezer kínai, és az év elején már további 65 ezer kérvény várt elbírálásra - a kanadai kormány ugyanis két évvel korábban befagyasztotta a folyamatot -, köztük 59 ezer volt kínai, ráadásul ebből 45500 Kína belső területeiről származott, annak ellenére, hogy Hongkongban adták be kérelmüket (Young 2014). 2014-ben, két évvel a program leállítása után a kedvezményes lehetőség megszűnt, és a befektetett minimumot 2 millió dollárra emelte a kanadai kormány, ráadásul kockázatitőkebefektető-alapokba, a személyes értéket pedig 10 millió dollárra emelték fel. A régi program csupán Québecben maradt meg, ahol viszont kvótákat állítottak fel. 2016 májusától már 1900 főben korlátozta az elkövetkező kilenc hónapra elfogadható befektetőivízum-kérelmek számát a québec-i tartományi kormány (Government of Québec). 2018-ban az új befektetőivízum-szabályzat ugyan akár egyszeri 175 ezer dolláros hitellel is hozzáférhetővé tette a vízumot, ám 1330 főben korlátozta a kínaiak számát, beleértve Hongkongot és Makaót is (Investor Visa Canada 2018). Ennek célja kifejezetten a korábbi kínai jelentkezők túlsúlyának enyhítése volt.

Ugyancsak magas a kínai kérelmezők aránya más országokban is. Az Egyesült Államok, Nagy-Britannia és Ausztrália esetében hatszor annyian igényelnek befektetői vízumot Kínából, mint az összes többi országból együttvéve (Cole 2014). 2014-ben, az USA-ban a befektetői vízumot kérelmezők 85\%-a, 2017-ben 76,9\%-a volt kínai, Ausztráliába pedig 2012 és 2018 között a befektetői vízumok 90\%-a érkezett Kínából és Hongkongból (U.S. Department of State 2014, 2017, Commonwealth of Australia). Továbbra is magas a kivándorlási szándék Kína gazdag családjai között. 2010-ben, 18 nagyvárosban végzett felmérés szerint az 1,6 millió dollár vagyonnal rendelkező személyek 60\%-a tervezett külföldre távozni, többségük az Egyesült Államokat és Kanadát jelölte meg célként (Bank of China and Hurun Research Institute 2011: 8).

Érdemes külön megemlíteni hazánk szerepét, helyzetét a befektetői vízumok kérdése kapcsán. A 2007-ben életbe lépett harmadik világból történő beutazást szabályozó törvény lehetővé tette (2007. évi II. törvény), majd 2013-ban létre is jött az ún. Letelepedési magyar államkötvények program, amelyből eredetileg 250 ezer euró, majd 2015-től kérelmezőnként 300 ezer euró össznévértékben kellett lejegyezni, vagyis vásárolni a letelepedési engedély kérelmezéséhez. Magát a kötvényt vállalkozások vásárolhatták, amik legalább ötéves futamidejű értékpapírt bocsátottak ki, és a fenti névértéken legalább 5 évig birtokoltak ilyen kötvényt (Államadósság Kezelő Központ). Ez tehát egyfajta befektetői vízum volt, amit 85\%-ban kínai befektetők vásároltak. Négy év leforgása alatt 6538 külföldi 
személy kapott letelepedési engedélyt befektetőként, és 13300 bevándorló kapott magyar letelepedési engedélyt családegyesités címén (Wiedemann 2017). Ha ezt a 20 ezer főt hozzáadjuk Nyíri (2010) legutolsó közölt becsléséhez, amely szerint 2006-ban 10-15 ezer kínai élt hazánkban, azt feltételezve, hogy a már itt élők számát a kiépített kereskedelmi kapcsolataik mentén ki- és belépők lényegesen nem változtatják, akkor a Magyarországon letelepedett kínaiak számát 35 ezer före becsülhetjük. Ha viszont azt feltételezzük, hogy a Nyíri becslése szerint Magyarországon élő 10-15 ezer kínai közt sokan nem rendelkeztek tartós letelepedési engedéllyel, akkor számuk lényegesen kisebb lehet a fentinél. Ezek a változások hazánkat regionális szinten jelentős befogadó országgá emelték a közelmúltban.

\section{Az oktatás}

Mindemellett a kivándorlás egyik legfontosabb összetevője éppen az az oktatás, amelyet annak idején az 1978-as reform célzott meg, amióta 4 millió2 (Xiang 2015: 282) kínai diák folytatott már tanulmányokat idegen országban. A legtöbb külföldön tanuló kínai gazdag, hiszen 97\%-uk maga finanszírozza tanulmányait, és legszívesebben azon országokat választják, ahol a legjobb egyetemek találhatók, így főként az Egyesült Államok és az Egyesült Királyság vonzó számukra. 2015-ben 523700 kinai diák tanult külföldön, köztük 200 ezer az USA-ban, ahol az átlagosan fizetett tandíj 36 ezer dollár évente, ami még a városban élő kínai átlagkeresetnek is a nyolcszorosa (National Bureau of Statistics 2014). Az évente kiutazó félmilliós diákságnak csupán a 70-80\%-a költözik haza, amikor elhelyezkedik a munkaerőpiacon; az összesen elvándorolt 4 millió diákból 2015-ig pedig mindössze 2,2 millió tért haza (ICEF Monitor 2016). A „csupán” itt természetesen a kínai vezetés értékítéletét tükrözi, amennyiben a külföldön tanulók mindegyikétől ezt várná el.

Nem magyarázza meg természetesen a kivándorlás egészét a tanulás, hiszen bármilyen jómódúak is ezek a fiatalok, a korábban említett befektetői vízumot megszerzők pl. már biztosan nem tanulók és nem is frissen végzett egyetemisták. Az az összefüggés viszont fennáll, hogy ők is külföldön tanultak korábban, hiszen a kínai munkaerőpiacon mindig is különösen értékes volt a külföldi diploma, így az az átlagosnál jóval nagyobb jövedelemhez segítette birtokosait. A külföldi élettapasztalat viszont hozzásegít a szélesebb látókörhöz,

\footnotetext{
${ }^{2}$ Az Oktatási Minisztérium becslése 3 millió.
} 
így a kínai közélet és társadalmi viszonyok középtávú alakulásának megítélése kevésbé lehet pozitív az ő körükben, beleértve a politikai rezsimet, a vállalkozói környezetet és a levegőszennyezést is (Xiang 2016: 5). Sőt, a gazdag családok gyerekeinek egyharmada már 16-18 évesen, középiskolás korukban is külföldön tanul (Hurun Research Institute 2013: 19); az Egyesült Államokban 2005 és 2011 között a középiskolában tanuló kínaiak száma tízszeresére nőtt (Xiang 2016: 8). ${ }^{3}$ A fiatalabb korosztályok megjelenése a kivándorlók között azonban csak az ezredforduló utánra tehető, részben éppen a külföldön dolgozók családtagjaként kerülnek az adott országba, részben viszont tudatosan választják a külföldi képzéseket már középiskolában is, ők leginkább a magas tandijú, elit iskolákba iratkoznak be.

Az egyre növekvő számú diák és befektető kivándorló mellett évről évre mind jelentősebb lesz a családegyesítés céljából emigrálók szerepe (Tichenor 2002: 216). Az 1970-es évek (az USA-ban az 1965-ös bevándorlási és állampolgársági tv.) óta a nyugati országok bevándorláspolitikájának középpontjában ez a szempont áll - habár Nagy-Britanniában, 2012-től minimumjövedelemhez kötik a családegyesítést is (UK Spouse) -, és a családegyesítés Ázsiában is az egyik meghatározó migrációs mozgatórugóvá kezd válni. A migráció hálózatos természetéből fakadóan a növekvő számú kivándorlás magával vonzza a családtagok késleltetett emigrációját is, így akár a befektetőket - akik általában a családtagjaik számára is érvényes vízumot vásárolnak vagy kapnak automatikusan - vagy a külföldön munkát vállaló magasan képzett szakembereket is követi a családja. Az EB-5 engedély az Egyesült Államokban átlagosan két családtagnak adott zöldkártyát (Brookings Institution 2014: 8) a múltban, a St Kitts \& Nevis-i vízum pedig minden családtagnak garantálja az állampolgárságot (St Kitts \& Nevis). Ausztráliába még a családegyesítéssel bevándorlók között is 17\% volt kínai 2013-2014-ben (DIBP 2014: 31-35). Ott mind a partner, mind a gyermek, mind a szülő számára kérhető vízumok közt Kína vezet, ám ez utóbbiban oly nagymértékben, hogy a teljes kérelmek felét teszi ki a kínai bevándorlók által beadott vízumkérelmek száma. A befogadó országok eltérő módokon reagálnak minderre. Amerika ugyan formálisan nem korlátozza a családegyesítéshez való jogot, de a várakozási idő egyre hosszabb, igy a kategória részaranya a bevándorláson belül csökken.

\footnotetext{
${ }^{3}$ Xiang Biao nem azt állítja, hogy a befektető bevándorlok között többségben vannak a külföldön tanultak - erről ugyanis adat nincs, a Hurun Report nem reprezentatív felmérés -, hanem csak azt, hogy általában véve a külföldön tanulás növeli a később megszerezhető jövedelem szintjét.
} 
Mindezek mellett, különösen a Délkelet-Ázsiában tapasztaltakhoz viszonyítva eltörpül a kínai szakképzetlen munkások kivándorlása. Évente mintegy félmillió munkást küld vagy fogad hazai, illetve külföldi munkaközvetítő, ez a létszám ugyan 1990 óta a tízszeresére nőtt, az utóbbi néhány évben még csökkenni is kezdett. 2015-ben pl. 530 ezren utaztak ki dolgozni, ez 32 ezerrel, azaz 5,7\%-kal kevesebb volt a megelőző évhez képest. Az ún. szerződéses munkák, amelyek lényegében a hazai munkaközvetítők által kiküldött munkaerőt jelentik, 253 ezer embernek adtak munkát más országokban, míg a munkaszolgálati együttmüködésnek titulált formában, ami a külföldi ügynökségek által szervezett munkát takarja, 277 ezren dolgoztak 2015ben. 2017-ben már csupán 12 ezer szerződéses és 16 ezer együttmüködéses alapon kivándorló munkást regisztrált a kínai Kereskedelmi Minisztérium (Ministry of Commerce 2015, 2017). A kettő nagyjából hasonló arányban oszlott meg a korábbi években is. 40\%-uk az iparban dolgozik, nagyrészt a textil- és élelmiszer-feldolgozó ágazatokban, egynegyedük építkezéseken, míg 15\%-uk a mezőgazdaságban helyezkedik el. Történetük nagyon hasonló más ázsiai országokéhoz, amennyiben az 1980-as években az Öböl-országok voltak elsőként a fő célpontok, majd az 1990-es évek háborúja után Ázsia egyéb területeire koncentráltak a munkaközvetítők, és mára 70\%-uk Kelet- és DélkeletÁzsiában dolgozik, ezen belül is a leggazdagabb országok, Japán, Korea és Szingapúr a legkedveltebb helyek (Xiang 2016: 9). Ezek az országok, mint pl. Szingapúr, elsősorban az olcsó, szerződéses munkaerőt keresik, de az 1985 óta oda vándorló kínai munkaerő számtalan problémával szembesül a rendszer hibáiból és a piac torzulásaiból adódóan, nem is említve a magas közvetítői díjakat, így pozíciójuk meglehetősen gyenge a munkaerőpiacon (Lin 2010).

A külföldi kínai munkaerő egyötöde Afrikában talál munkát, ami egyértelmüen a bővülő kínai beruházásoknak köszönhető, így az sem meglepő, hogy szinte mindegyikük kínai munkaközvetítéssel kerül oda és nagy építkezéseken dolgozik (Park 2009: 2). De megjelentek kínai munkások Oroszországban is. Az 1991-1993-ban vízummentessé vált kínai beutazás új fordulatot hozott a két ország kapcsolatában. 2001-ben aláirták a Szerződés a jó szomszédságról és barátságos együttmüködésről a Kinai Népköztársaság és Oroszország között elnevezésű megállapodást, (Ministry of Foreign Affairs), miközben ebben az évben már 35 ezer kínai élt Oroszországban. Igaz, Szergej Prihogyko, az akkori Elnöki Hivatal helyettes vezetője ennél jóval többre, 150-200 ezerre becsülte számukat (Wishnick 2005: 79). 


\section{A KÍNAI KIVÁNDORLÁSPOLITIKA KIALAKULÁSA}

Kínában a kivándorlás kérdése elsősorban a hatalmas diaszpórához kötődik és csak másodsorban a határrezsimhez, munkaerőpiaci szabályozáshoz, munkaerő-közvetítő cégekhez, vagy a még ezeknél is komplexebb illegális határátlépésekhez és embercsempészethez. Míg a diaszpórával kapcsolatban egy viszonylag egységes és következetes hozzáállást tapasztalhattunk az elmúlt évszázad legkülönbözőbb korszakaiban, addig az utóbbiak sem külön, sem együttvéve nem képeztek egységes politikai koncepciót Kína modernkori történelme során. Még a maoista rendszer is igyekezett a nemzettest részeként pozitívan viszonyulni a más országokban élő kínaiakhoz, azok integrációját segíteni, habár eltérő eszközökkel és leginkább sikertelenül. A kivándorlás szemléletében azonban hatalmas változás következett be a Csing, majd a nacionalista időszak, a maoizmus szakaszai és végül a Teng Hsziao-pinggel kezdődő új korszak nyomán. Az 1980-as évektől a kínai kormány elválasztotta a kivándorlás kérdését az uralkodó politikai rendszer elvi megfontolásaitól, és sokkal inkább kezdte úgy kezelni mint szolgáltatást és nem mint korlátozást. Mindez mára egyértelműen Kína előnyére szolgálna, ha a migráció kérdését sikerülne elválasztania az általánosabb politikai kérdésektől is, és ezzel meggátolnia a nemzetközi véleményt attól, hogy beleszóljon az ország belügyének tekintett emberi jogi kérdésekbe.

\section{A kivándorlás kérdése 1949 után}

A kivándorlás jogi szabályozása olyannyira új keletű Kínában, hogy az 1949-ben alakult Népköztársaság nem is hozott létre ilyeneket. Egészen 1957-ig csupán rövid direktívák szabályozták a kilépési limiteket és egyszerüsített ki- és belépési szabályzatok voltak érvényben; első volt ezek sorában az 1951-es /deiglenes szabályzat a határon túli kinaiak országhatáron ki- és belépéséröl. Ehhez érvényes útlevél és vízum szükségeltetett, annak hiányában pedig egy, az adott személynek a határon túli kínai helyzetét igazoló okmány (Liu 2006: 135). Ezen kívül csupán az ún. hukou, a háztartás-nyilvántartás szolgált valamelyest kézben tartani a népesség alakulását befolyásoló demográfiai folyamatokat, illetve ellenőrizni az esetleges illegális tartózkodást. Ebben a rövid, kezdeti időszakban a nemzetközi vándorlással elnézően bánt a kormány, az elsődleges szempont a határon túliak hazatelepülése lett volna, azzal a céllal, hogy segítsék újraépíteni az országot; és 
valóban a határátlépők nagy része csak külföldön élő kínaiakból és hongkongi, makaói polgárokból állt (Liu 2009: 313). A hazalátogatás vagy -település 1949 és 1957 között nőtt is évente 15-20\%-kal, még ha gátolta is valamely ország a visszatérést Kínába, ez Hongkongon és Makaón keresztül közvetve sikerülhetett.

Kína persze igyekezett nemzetközi kapcsolatrendszerét úgy alakítani, hogy mindezt segitse, 1955-ben alá is írt az Egyesült Államokkal egy egyezményt a polgári személyek visszatérésével kapcsolatban. Ugyanis 1949-ben, amikor kikiáltották a Népköztársaságot, majd 1950-ben, a koreai háború kitörésekor Kína nem engedte ki az amerikai és koreai állampolgárokat az országból. Amint kiderült, hogy az Egyesült Államok nem ismeri el a Kínai Népköztársaság kormányának szuverenitását, az amerikai misszionáriusokat, üzletembereket és tudósokat vagy letartóztatták, vagy megtagadták tőlük a kilépést az országból. Ezzel szemben a Kínai Köztársaság Tajvanra menekült kormányát ismerte el. A kínai diákoknak ugyanezen az alapon tagadták meg a visszatérését a Népköztársaság kormánya által ellenőrzött területre (Oyen 2016). Az amerikai kormány erre reagálva, szükségállapotot hirdetett, megtagadta az 5 ezer ott tartózkodó kínai diák és minden olyan technikai szakember hazatérését, aki hathatósan segithetett volna Kína újjáépítésében (Office of the Historian). A 30 évig tartó diplomáciai kapcsolatok nélküli viszony a két ország között nem volt egyszerü. Az 1955. augusztusban megindult tárgyalásokat megelőzően az Egyesült Államok márciusban aláirt Tajvannal egy védelmi megállapodást, annak következtében, hogy a megelőző évben Kína bombázta a sziget partjait (U.S. Department of State, Historical Office: 945). A tárgyalások ilyen feszült helyzetben is sikeresek voltak ugyan, ám Kína azt akarta elérni, hogy az USA minden kínait küldjön haza, ezt azonban ők megtagadták, mondván, csak azokat engedhetik haza, akik akarnak is menni, ezzel szemben, akik maradni akarnak, azok megtehetik. Ilyen átfogónak korántsem mondható töredékekből épült fel Kína migrációs politikája a Népköztársaság korai éveiben.

A kínai állampolgárok és az idegenek is csak kilépési engedéllyel hagyhatták el az országot, az 1951-es szabályzat harmadik bekezdése értelmében ezt az engedélyt a városi vagy területi hatóság állította ki. 1954-ben egy újabb ideiglenes szabályzat már személyes kérelemhez kötötte az idegenek kilépési engedélyét, és csak alapos vizsgálat után adhatta ki a kilépési vízumot vagy igazolást, attól függően, hogy az adott ország, amelynek polgáráról volt szó, diplomáciai kapcsolatban állt-e Kinával vagy sem. Az útlevelek kiállitása és természetesen minden egyéb kapcsolódó feladat a Külügyminisztérium hatáskörébe tartozott. Ám az újonnan alakult Kínai Népköztársaság számára a határ nem csupán technikai fogalom volt, hanem - és ez a tendencia idővel egyre erősödött - a kommunista 
és a kapitalista világ közötti választóvonal is egyben. ${ }^{4}$ Ilyetén tulajdonságánál fogva sokkal jobban átpolitizálódott, mint ahogy egy modern nemzetállamnál általában megszokott. 1957-ben az összes be- és kilépési adminisztráció átkerült a Közbiztonsági Minisztériumhoz és a helyi közbiztonsági hatóságokhoz. 1956-ban az Államtanács ugyanis kiadott egy körlevelet, amely a Közbiztonsági Minisztérium ki- és belépésekkel kapcsolatos egységes felelősségéről szólt. Egy, a tartományi szervek köré épülő adminisztráció kiépítése segitette a munkáját ezentúl (Liu 2009: 313). A paranoid jelleg bizonyos mértékig már 1951-ben érvényesült, amennyiben egy, a kormányzat által kiadott kiáltvány külön szabályozta Hongkong és Makaó felé irányuló kilépéseket, és azokat már akkor a Közbiztonsági Minisztérium hatáskörébe utalta. Persze ebben az időszakban Hongkonghoz és Makaóhoz közel eső dél-kínai tartományok, mint pl. Kuangtung, illetve a Tajvannal szemben fekvő Fucsien bizonyos mértékig veszélyesebb területnek számítottak a kapitalista területekhez való közelség okán, ennélfogva gazdaságilag és közigazgatási értelemben is elhanyagolták azokat. Ez ugyan rosszat tett a térség fejlődésének, viszont nagyobb szabadságot hagyott az embereknek, mivel az ellenőrzés is lazább volt (Thunø - Pieke 2005: 489).

A maoista Kína Magyarországhoz és a többi kommunista országhoz hasonlóan, üldözte a korábbi földtulajdonosokat mint kizsákmányolókat, így azokat, akiket nem gyilkoltak meg, 1949 után vagy bujkáltak, vagy elmenekültek az országból. Az 1950-1953 között zajló földreform különösen nagy hatással volt a migrációra, hiszen a földbirtokláson alapuló klánokat is szétzilálta, ezzel és a határon túli rokonoktól elkobzott földekkel Kína a diaszpóra lojalitását is megrendítette, ami egyben az otthoni rokonok anyagi támogatását is akadályozta (Choi 1975: 57-58, Hinton 2006: 37-87). Ugyancsak elmenekültek a volt politikai vezetők és vezető értelmiségiek nagy része is a sztálini mintára berendezett új Kínából (ezek egy része később visszatért) (Bernstein 2010, Brown - Rosemary 1994). Az egyén szintjéig terjedő ellenőrzést szolgálta a szintén 1951-ben, az ideiglenes szabályzással alapított háztartás-nyilvántartás is. Habár az eleinte nem korlátozta a lakóhely-változtatást a városokon belül, amelyekre eredetileg kidolgozták, ám 1955 után Kína egész területére kiterjedt a hatálya, és akkortól csupán a saját lakóhelyen lehetett útlevelet vagy kilépési engedélyt igényelni. Ráadásul 1951-ben a növekvő nyomás miatt, más országokat követve Hongkong is felfüggesztette a szabad belépést a Népköztársaság állampolgárai számára, erre reagálva a következő évtől Kína is hasonló engedélyhez kötötte a kilépést Hongkongba és Makaóba (Liu 2009: 317).

\footnotetext{
${ }^{4}$ Természetesen határon itt a kapitalista országokkal összekötő határokat, főként a repülőtereket és a kikötőket értjük.
} 
A szovjet hatás 1949 és 1956 között folyamatosan erősödött. Kína szinte válogatás nélkül vette át a Szovjetunióban megszületett szabályokat, intézményeket (pl. ötéves tervek). 1960-ig 10 ezer szovjet tanácsadó dolgozott Kínában, akkor azonban Hruscsov visszahívta őket - azok munkája ugyanis a nagy ugrás miatt évek óta teljesen ellehetetlenült (Bernstein 2010: 1). Ebben az időszakban a legfontosabb külföldi ország, ahol kínai diákok tanulhattak, a Szovjetunió volt (emellett más kommunista országokban is volt rá lehetőségük), akik akkor ott tanultak, még ma is jelentős szerepet játszanak a közéletben. 1956-ban azonban Mao stratégiája is fordulatot vett. Nem szabad mindent lemásolnunk a hibáikkal együtt - mondta ki a végszót a szovjet mintától való elforduláshoz, majd nagy ugrással elindította első saját reformstratégiáját. Az 1956-ban meghirdetett kampányjelszó a „Virágozzék száz virág, versengjen száz iskola” a következő évre átcsapott a jobboldali „elhajlók elleni” kampányba (Short 2001: 470, Meisner 1999: 155-191). A Szovjetunióban tanult ellenzéket külföldi feleségeikkel és családjukkal együtt munkatáborokba vitték, ahonnan már biztosan nem távozhattak külföldre. Mindenki, aki csak menni akart, hallgatott a félelemtől, nehogy sorsukra jusson. 1964-ben aztán megszületett a Külföldiek belépése, kilépése, átutazása és utazása adminisztrációjának szabályozása, ami gyakorlatilag minden nem kínai állampolgár számára bármilyen helyváltoztatáshoz vízumot írt elő. A kulturális forradalom évtizede alatt már mindenki, aki kilépési engedélyért folyamodott a rendszer ellenségének, kollaboránsnak, a kommunizmus árulójának, vagy feltételezhetően valamilyen illegális, Kína ellen irányuló összeesküvés tagjának minősült. A szabályzat még azt is előirta, hogy mely pontokon, milyen járműveken és pontosan milyen célpontba utazhat ki a vízum tulajdonosa, de még a külföldön élők is csak 1974-ben kaptak újra engedélyt, hogy hazalátogassanak rokonaikhoz (Liu 2011: 7-8). Természetesen még egy ilyen zárt autoriter rendszerben is létezett a legális kiutazás mellett a Népköztársaság által is elfogadott külföldi letelepedés, legfőképpen Hongkongba (Madokoro 2016: 174), még ha nem is volt jellemző.

\section{Szabályozás és kivándorlók 1978 után}

1978-ban aztán újra enyhítettek a korlátozáson, és júniusban közzétették a Javaslatok a Közbiztonsági Minisztérium, a Külügyminisztérium és az Államtanács Külföldi Kinaiak Hivatala részéről az országból való kilépés szabályozásának enyhitésére és fokozására, a hazatért külföldi kinaiak és családtagjaik helyzetének vizsgálatára és jóváhagyására elnevezésủ dokumentumot, amelynek ered- 
ményeként ugyan némi enyhülés következett be, de még hosszú évekig nem történt semmilyen alapvető változás a kivándorlás szabályozásában. További enyhítés legközelebb csak 1984-ben lépett életbe, egy újabb hasonló javaslat (ami lényegében rendelet) keretében, amit ráadásul egy körlevélben kiküldött utasítással kellett megerősíteni, mert a helyi közigazgatási hatóságok konzervatív maoista irányítása nem akarta azt végrehajtani (Liu 2006: 140). De történtek ezalatt olyan változások, amelyek, ha nem is közvetlenül, de közvetve mégiscsak befolyásolták a migrációt. Ilyen esemény volt pl. a Különleges gazdasági övezetek létrehozása 1979-ben, majd 1984-ben a tizennégy, partvidéki beruházásokra hivatott városi központ megnyitása. Mindegyik exportorientált, magánbefektetői és a nyugati országokkal, de elsősorban Hongkonggal, illetve Makaóval kapcsolatot tartó intézmény volt, és mind a délkeleti országrészben helyezkedett el. A korábban elhanyagolt tartományok ettől kezdve rohamos fejlődésnek indultak, mára a gazdaság motorjává váltak, és jelentős mértékben tudták ezek után a diaszpórát helyi gazdaságukba involválni. A tőkekivitel és a külföldi kapcsolatok egyre inkább arra késztették az itt élő szegényeket, hogy külföldön vállaljanak munkát, és a térség hagyományosan külföldre is kiterjedt rokoni kapcsolathálója is nagymértékben hozzájárult ahhoz, hogy Dél-Kína ezt követően újra a legjelentősebb kivándorló térséggé vált. Továbbra is ez volt a legkevésbé ellenőrzött területe az országnak, 1979 után ez is hozzájárult ahhoz, hogy tömeges kivándorlás induljon meg, azonban mindezekkel egyidőben a szegényebb rétegek tudatlanságával visszaélve, máig tartó jelentős embercsempészet is kezdetét vette (Chin 1999: 3).

A Kína déli tartományai, Jünnan, Kujcsou, Kuanghszi és Szecsuán egyes részei, valamint a Mekong vidékén elterülő államok, Vietnam, Laosz, Mianmar és Thaiföld hegyvidékes térségei olyan sajátságos, az állami kormányzatok politikája által nehezen elérhető területeket jelentenek, amelyek leginkább az emberiség azon korszakára emlékeztetnek, amely megelőzi az öntözéses rizstermesztés és a buddhizmus térnyerésével megjelenő modern korszakot „Zomia” egy nem valóságos terület, nincsenek történeti intézményi keretei, földrajzilag is vitathatóak a határai, ám az érintett államok migrációs politikáiban érezhetően homályos pontot fognak jelenteni, és a régió körülhatárolásának is bizonytalanságot kölcsönöz máig fennmaradó önirányítása (Scott 2009: ix-x). Ezen a területen zajlik a legnagyobb mértékü illegális határforgalom, beleértve a személyi és tárgyi összetevőket is. A személyek csempészése elsősorban az Észak-Koreából menekültek kiléptetését jelenti - éppen amiatt, hogy itt a legkönnyebb ezt megtenni -, de beletartozik a szomszédos országok és Kína között kialakuló családi kapcsolatok kusza rendszere is. Ez lényegében azt jelenti, hogy már egyik ország ha- 
tóságai sem tudják nyomon követni, hogy az érintett területen ki kivel él együtt, alapít családot, és Kína részéről jelentős mértékben szemet is hunynak fölötte.

„Gyorsits, ha látod, hogy zöld a lámpa, lassan haladj, ha sárga, és kerüld meg a piros lámpát!" - hangzik egy igen gyakori mondás a kínai hivatalnokok szájából (Xiang 2006: 35). Ez a szemet hunyó magatartás egyébiránt inkább ártott az embercsempészetnek és sokkal inkább kedvezett a határkereskedelemnek, ám már nemcsak a vietnami, hanem az 1980-as évek második felére az orosz, a mongol és az észak-koreai határon is (Nasolomampionona 2014: 29). De még az 1984-es határozat (javaslat) első bekezdése is előirta, hogy a határátlépéseknél a jelentkezőt kell segíteni, az ő szándékai, kijutása fontosabb, mint a procedúra lefolytatása. Mindez fura ellentmondásban volt az 1980-as Vízum és útlevél szabályzattal, amely ugyan már megengedte, hogy bizonyos képzettségekkel rendelkező személyek kiválthassanak útlevelet, az ország elhagyásához még mindig szigorú vizsgálatot rendelt el. A „speciális képzettség” kritériuma pedig annyit jelentett, hogy ugyanakkor állami hivatalnok vagy állami vállalat alkalmazottja az illető (noha az alkalmazás nem képzettség). A helyzet abszurditásához tartozik, hogy a kommunista párt tagjai még nehezebben utazhattak személyes ügyekben külföldre, mint bárki más. Nekik a helyi munkabizottság és a közbiztonsági hatóság külön hozzájárulására is szükségük volt, amit aztán a felettes pártbizottság is kivizsgált. Az ország lakosságának kivándorlása így meglehetősen vegyes képet mutatott, egyik oldalon igen korlátozott lehetőségeket nyújtott, másutt meg szinte teljesen átjárhatóvá tette a határokat (Liu 2009: 316).

1980-ban hozták létre a kilépő vízum rendszerét, az így életre hívott kilépő okmányt mindenkinek, minden egyes alkalommal ki kellett váltania, aki csak el akarta hagyni az országot. Kivételt azok képeztek, akik gyárat alapítottak, vagy egyéb beruházást hoztak az országba, esetleg olyan külföldiek, akik házat vettek Kínában, de abban az esetben huzamosabb idejü életvitelszerủ tartózkodás is feltétele volt a többszöri kilépési engedélynek. 1979 és 1985 között 50 ezer, 1986 és 2001 között már 400 ezer ki- és belépési engedélyt adott ki a Közbiztonsági Minisztérium. 1986 tehát a számok tekintetében is érzékelhetően vízválasztó a kínai migrációs politika fejlődésében. Ennek azonban csak egyik oka az új, migrációt szabályozó törvény. Elsőként szólni kell arról, hogy ekkor jelentek meg az élethosszig tartó munkaviszonyokat felváltó szerződéses alkalmazások, aminek révén lehetővé vált a vállalatok számára, hogy önállóan vegyenek fel vagy bocsátsanak el alkalmazottakat. Ugyanakkor megerősödött a helyi önkormányzatok ellenőrző szerepe a vállalatok fölött (Soler-Matutes 2000), ami sokszor nagyarányú elbocsátásokhoz vezetett, ezzel olyan munkaerőpiaci túlkínálatot teremtve, amely eredményeként részben a nagyvárosokban, de az 1990-es évek 
végétől már sokszor külföldön is tudtak munkát keresni. Habár ez elsősorban a belső vándorlás drasztikus emelkedésében volt tapasztalható, különösen a gyorsan fejlődő délkeleti területeken, az 1990-es évektől az addigra már egyre inkább elavuló északkeleti iparterületekről is egyre nagyobb lett a kivándorlás (Xiang 2016: 10). Mindez egyben felvetette a migrációs hajlandóság volumene és a népességeloszlás egyenlőtlenségeiből származó kedvezőtlen folyamatok mérséklését, ezáltal a szabályozás szükségességét erősítette. (Hautzinger et. al. 2014: 8).

\section{A KIVÁNDORLÁS JELENLEGI JOGI ÉS INTÉZMÉNYI KERETEI}

A személyi igazolvány 1986-os bevezetése szintén jelentős lépésnek bizonyult a migráció intézményesülésében, hiszen korábban csak az egész családnak kiadott háztartás-nyilvántartási vagy a munkahelyi igazolás szolgálhatott hivatalos dokumentumként. Habár az új igazolványt éppen a személyek feletti kontroll erősítésére és különösen a bünüldözés ellen vezették be, valójában a személyes szabadság eszközévé vált, amennyiben lehetővé tette minden állampolgár számára, hogy útlevelet igényeljen, bankszámlát nyisson, pénzt utalhasson, repülőjegyet vehessen, vagyis összességében független gazdasági szereplővé váljon. A legjelentősebb változás a fordulat évében, 1985-ben mégiscsak az 1986. február elsejétől hatályos, Az állampolgárok ki- és belépésének szabályzásáról szóló törvény lett (President of the People's Republic of China - Citizens). 1986-ban született meg A külföldiek ki- és belépéséröl szóló törvény is (President of the People's Republic of China - Aliens), amelynek deklarált célja a személyi jogok biztosítása és a nemzetközi csere fokozása volt, habár a külföldiek kifejezett elismerése továbbra is kimaradt belőle. Még ugyanebben az évben megjelent a hazai és a külföldi állampolgárokra vonatkozó részletes szabályozás is, ám a számtalan kiegészítő rendelkezés, direktíva és körlevél miatt továbbra is meglehetősen kétértelmű maradt a migráció szabályozásának helyzete. 1980 és 1994 között összesen 235 ilyen jogszabály és irányelv lépett életbe, amelyeket 42 különböző intézmény alkotott meg (Liu 2009: 317). Mindehhez a nagyközönség még csak nem is fért hozzá, lévén az információ nem szabadon terjeszthető termék az országban, a bürokrácia így zavaros, átláthatatlan maradt, és egyáltalán nem kedvezett a vándormozgalomnak.

Az útlevélkérelem hosszadalmas procedúra volt: igazolások a nyilvántartásból, fogadónyilatkozat általában leginkább egy külföldi rokontól - ezek voltak 
a legfontosabb dokumentumok, amiket csatolni kellett, de ekkorra legalább már a kilépési regisztrációs kártyát és vízumot eltörölték. 1992-ben a többszöri kiutazás is egyszerűsödött: a korábban még mindig szükséges regisztrációs kártyát megszüntették ez esetben is, és a vezető kutatók, technikai szakemberek, illetve személyzetük számára már közigazgatási igazolás sem kellett többé a kilépésekhez. 1996-ban eltörölték a formális meghívólevelet, amely korábban szükséges volt az ország elhagyásához, 2000-ben pedig lehetővé vált, hogy külföldideviza-betét esetén is igényelhessen kínai állampolgár útlevelet (Liu 2009: 317).

Mindeközben zavartalanul fejlődött a határ menti kereskedelem, ami szükségessé tette a határellenőrzés fejlesztését. Különösen a déli tartományokban szigorították a határőrizetet, a határállomások vezetői súlyos szankciókban részesülnek ma is, amennyiben embercsempészeket találnak a hozzájuk tartozó megyében. Az illegális határátlépések oly mértékben növekedtek az 1980-as éveket követő két évtizedben, hogy az ezredfordulóra már 95 ezer illegális kínai munkás élt Koreában, 100 ezer Japánban, és hatalmas hullámokban érkeztek Oroszországon keresztül Európába. De egyre nőtt a számuk az Egyesült Államokban, Ausztráliában és Délkelet-Ázsiában is (Chin 2003: 50). A határrezsimek fontos szerepet játszanak a migráció szabályozásában, ám szerepük jóval inkább biztonságpolitikai vonatkozású, mint gazdasági vagy belpolitikai. Ez Kína esetében is megmutatkozik, amennyiben még az 1996-ban létrejött Sanghaji Ötök, illetve a 2001-ben létrehozott Sanghaj Együttmüködési Szervezet közép-ázsiai geopolitikai szerepét is figyelembe vesszük, ráadásul amihez 2017-ben India és Pakisztán is csatlakozott (TRT World 2017).

Az 1980-as évek közepétől tehát számos formában indult meg változás, de a rohamosan növekvő kivándorlás szabályozása továbbra is kaotikus maradt. 1981-ben az Államtanács kibocsátott egy ideiglenes szabályozást az önfinanszírozott külföldi tanulásról, ami elsőként elismerte az egyén jogát, hogy állami támogatás (és kontroll) nélkül külföldön tanulhasson (Xiang 2003: 29). Az 1989-es Tianamen téri mészárlást követően pl. a külföldi országokban menedéket kérő kínai diákok száma oly mértékben felduzzadt, amely csak a 19. századi kivándorlási hullámmal vethetö össze (Wichberg 1994: 16). Mindeközben a kínai vezetés igyekezett konszolidálni a helyzetet, így 1992-ben már megszületett egy ideiglenes jogszabály, ami megteremtette a lehetőséget a határon túli munkaerőt foglalkoztató ügynökségek létrehozására Kínában, és ezzel lehetővé tette azt is, hogy magánszemélyek önállóan vállaljanak munkát külföldön, egyúttal a Munkaügyi Minisztérium felállította a Külföldi Foglalkoztatás Hivatalát (Xiang 2003: 33). 1994-ben a Munkajogi törvény liberalizálta a munkaerőpiacot. A gazdasági 
reformokkal együtt ez 40 millió, állami vállalatoknál betöltött állás elvesztését eredményezte (Liu 2014: 11). Ugyanebben az évben egy államtanácsi körlevél azt is elrendelte, hogy politikai nézeteitől függetlenül minden visszatérő diákot további nyomozás nélkül haza kell engedni. 1996-ban ennek részletes szabályozása is hatályba lépett, majd 1999-ben egy, a külföldi tanulást segítő ügynökségek létrejöttét és működését szabályozó rendelet is keletkezett (Liu 2009: 318). Mindeközben Kína gazdasága a szocialista piacgazdaság útján egyre növekedett.

A nemzetközi kereskedelmi, tudományos és számtalan egyéb területre kiterjedő kapcsolatok mind jobban visszafogták az államot a migrációt szigorúan korlátozó általános elv gyakorlásában. Kína WTO-taggá válása 2001-ben szintén fokozta az igényt a ki- és belépések szabályozásának leegyszerüsítésére. Az 1990-es években egy átlagos kínai fiatalnak ugyan már könnyebben lehetett külföldön tanulni, azt a kritériumot továbbra is fenntartották, hogy semmilyen politikailag kifogásolható magatartást nem mutathatott az illető. Másfelől az ország elhagyása - és a belépés is - még mindig sokkal inkább tartozott a kormány ellenőrzése alá, mintsem a szabad akarat kérdéséhez. A helyi bürokráciához kötődő kapcsolatok ráadásul nagymértékben befolyásolták azt, hogy mennyi idő alatt jutott hozzá valaki az útleveléhez (Shi 1995: 180).

Az államigazgatás jelszava az ún. tizenkét szavas megközelités jellemezte ezt az átmeneti évtizedet: „Támogatni a külföldi tanulást, bátorítani a visszatérést, garantálni a szabad lakóhely-változtatást!" (Xiang 2003: 29). A kormány 1996-ban fel is állított egy ösztöndíjbizottságot az Oktatási Minisztériumban, ami abban az évben 1900 diákot segített hozzá, hogy 80 különböző országban tanulhasson vagy kutathasson. 2006-ra az ösztöndíjasok száma már 5580-ra nőtt, amit, ha kiegészítünk a többi állami vagy intézményi támogatásban részesülő diákok számával, akkor együttesen az ekkor összesen külföldön tanuló 134 ezres kínai diákság nagyjából 10\%-át adta (Liu et al. 2013: 15). 1999-ben elindulhattak a külföldi tanulást segítő ügynökségek is, ám a következő években a legtöbbet be kellett zárni különböző pénzügyi botrányok miatt, végül 2013-ban létrejött a Bizottság a saját-finanszírozású külföldön tanulást segítő szolgáltatásokhoz, ami egy 88 ügynökséget tömörítő egyesület lett, célja a szolgáltató iparág alapelveinek, politikáinak felállítása, a tagok támogatása és mindenféle általános érdekvédelem (Committee on Self-Funded). Ezzel a civil szféra fejlődése is jelentős lépést tett a kivándorlás intézményesülési folyamatában, és ugyan a munkaerő külföldi kiközvetítése nem vált meghatározó, de még jelentős iparággá sem Kínában, annak modern piaci keretei mégis létrejöttek az ezredfordulóra. Noha már 1992-ben 221 hazai vállalatnak volt engedélye, hogy külföldön foglalkoztas- 
son embereket, az új évezred első évében 48 kifejezetten munkaerő-közvetítéssel foglalkozó cég müködött Kínában, még 2013-ban is csupán 527 ezer képzetlen munkás utazott külföldre munkát vállalni (Xiang 2016: 8).

A határátlépést szabályozó adminisztráció fejlesztésére 2001-ben hat reformcélt határoztak meg, amelyből négy a kivándorláshoz kapcsolódott, továbbá egy turisztikai és egy vízumpolitikai döntés is született. A középpontban azonban egyértelmủen az állt, hogy minden állampolgár külön írásos engedély nélkül igényelhessen útlevelet egyéni céljai szerint. Emellett eltörölték a meghívólevelet, külön kínai sávot hoztak létre a repülőtereken, és megszüntették a korábbi korlátozásokat, amelyek a Hongkongba és Makaóba utazókra vonatkoztak (Liu 2006: 151). A kiutazással kapcsolatos reformok fokozatosan váltak mind pragmatikusabbá, így pl. kiterjesztették a közvetlen útlevéligénylést száz közepes és nagyvárosra, főként az ország belsejében, vagy pl. az egy évnél hosszabb időt külföldön dolgozók lakóhely-nyilvántartását sem vonták be többé. Megreformálták az útleveleket is, négyféle típust kibocsátva: diplomata, nyilvános, közönséges, valamint külön Hongkongba és Makaóba érvényes útleveleket, majd a 2006-ban beiktatott útlevél törvény már csak háromféle típust határozott meg. A közönséges útlevél nem hivatalos célokra szolgál, mint üdülés, rokonlátogatás, tanulás, munka, üzleti célok; ezt a Közbiztonsági Minisztérium Ki- és belépési Hivatala állítja ki. A diplomata útlevelet a Külügyminisztérium szolgáltatja a dipIomaták és családtagjaik számára; a szolgálati útlevél pedig szintén a Külügyminisztérium hatásköre az állami alkalmazottak és a nemzetközi szervezetekhez delegált munkatársak részére (Embassy of the People's Republic of China). Az új évezred elején megindult reformok tehát nagyban leegyszerüsítették a kivándorlás adminisztratív korlátait, noha továbbra is maradtak hiányosságok benne, a legfontosabb jellemzője mégiscsak az volt, hogy az állam ellenőrző, az egyén szabadságát korlátozó jellege mind inkább elhalványult.

A Népköztársaság megszületését követő földreform annak idején gyakorlatilag eltörölte a magántulajdont. Ezután majd az első maói reformot követő változások a közösségi tulajdon és a magánjellegű földhasználat történelmi kettősségét helyezték kommunista keretek közé (Rithmire 2015: 36-40). A magántulajdon szempontjából azonban mindenképpen alapvető korlátot jelentett, hogy azt elidegeníteni nem lehetett. 1998-tól az állam kezdte kedvezményes keretek között kiárusitani a többségében állami tulajdonú lakásokat a városokban (Yang - Chen 2014: 15-45), és ami történelmi fontosságú, hogy az új, 2007-es földtör-

\footnotetext{
${ }^{5}$ A magántulajdon 1950-es megszüntetése nem keverendő össze a későbbi kollektivizálással, így hatása sem a közös használatból eredő korlátokat, hanem az elidegeníthetetlenséget jelentette elsősorban.
} 
vény (Ministry of Land and Resources) lehetővé tette annak magántulajdonba vételét. Ez a lehetőség azzal a következménnyel járt, hogy a tulajdonos eladhatta, jelzálogot vehetett fel rá (Chen 2011: 82), annak ellenére, hogy a föld továbbra is állami tulajdonban maradt. Ez a speciális használati jog lehetőséget teremtett, hogy a potenciális migránsok mintegy garanciaként, biztosítékként használják tulajdonukat a hitelezők, a külföldi nagykövetségek felé és leginkább a közvetítőcégekkel való ügyleteik során. A közjegyzői hivatalok létesítése ugyancsak olajozottabbá tette ezen tevékenységek adminisztrációját (Xiang 2016: 11).

2002-ben három intézmény, a Munkaügyi, az Állambiztonsági és a Közbiztonsági, valamint az Ipari és Kereskedelmi Minisztérium együttműködésében megszületett a 15. sz. határozat a munkaerö külföldi alkalmazásáról (Liu 2008: 3). A magáncélú munkaközvetítés a felelősséget a külföldi foglalkoztatóra, a hazai közvetítőre - rögtön 2002-ben 412 ügynökség jelentkezett - és a magánszemélyre hárította, az állami monopólium megszűnt (Xiang 2012: 48). Napjainkban a közvetítőcégeknek négy típusa müködik: oktatási, munka, általános kivándorlási és turisztikai célú ügynökség. Végül pedig 2012-ben megszületett a migrációs törvény, amely régóta váratott magára. A 3. cikk első bekezdése egyértelműen kimondja, hogy az állam védi az országot elhagyó és az országba belépő kínai állampolgárok törvényes jogait és érdekeit (The State Council). Mára a feladatkörök is egyértelművé váltak. A Közbiztonsági Minisztérium Ki- és belépési Hivatala felelős a kilépések adminisztrációjáért, együttműködésben a tartományi közbiztonsági hivatalokkal. Minden határátkelőhelyen van ellenőrzési pont, továbbá Határnyomozati Állomás működik Pekingben és nyolc másik nagyvárosban. Az Oktatási Minisztérium felel a diákok külföldi tanulmányaiért, a Kereskedelmi Minisztérium a külföldi foglalkoztatásért (Liu - Du 2014: 9).

Ugyancsak 2012-ben keletkezett a Szabályozás a külföldi munkaerö-szolgáltatás együttmüködésének irányitására elnevezésű törvény, ami pontosan előírja azon kritériumokat, amelyeknek a hazai közvetítőcégeknek meg kell felelni, mind a gazdasági garanciák, mind a munkahelyi feltételek biztosításának tekintetében. Ide tartozik tehát a megfelelő tőke, személyzet biztositása, vagy a fogadó ország körülményeinek ismerete: legalább 6 millió jüan alaptőke, (a fele folyószámlán), pontosan meghatározott szerződéses feltételek, benne a fizetés, a szabadság, a személyes szabadság biztosítása és szinte minden egyéb olyan részlet, amire a korábbi problémák, vagy más országok rossz tapasztalatai megtaníthatták a törvényalkotót (Ministry of Commerce 2012). A törvény figyelemmel van a fogadó országok kivánalmaira is. A Kína és Japán által felállított keretfeltételeknek megfelelően, pl. ha egy japán vállalat kínai munkásokat akar foglalkoztatni, akkor foglalkoztatási tervet kell benyújtania a helyi ipari szövetséghez Japánban, 
amely saját felelősségére megkéri a megfelelő kvótát a nemzeti szövetségtől. A kérelem továbbmegy a kormányhoz, és ha az elfogadja, akkor tovább küldi azt a kínai közintézményhez, ami ezután eljuttatja a megfelelő engedéllyel rendelkező, nagyvárosokban működő, tőkeerős munkaerő-közvetítő cégekhez, akik pedig sokszor továbbadják a munkakeresést a nem kvalifikált, alsóbb szintű, ám a munkásokkal közvetlen kapcsolatban lévő kapcsolattartókhoz (Xiang 2016: 13).

Még 2004-ben megalakult a tárcaközi munkacsoport találkozó a kínai állampolgárok és jogi személyiségek jogainak védelméröl külföldön, amelynek szabályzata ugyancsak a közvetítőcégek ellenőrzését szigorítja. A kínai kormány 2016-ra már több országgal is aláirt bilaterális egyezményt a munkavállalással kapcsolatban, közülük a legfontosabbak: Japán, Korea, Oroszország, Malajzia és Bahrein. Mindezek és annak ellenére, hogy a Határon Túli Kinaiak Hivatala felelős a kiküldött szakképzetlen munkaerőért és a kinn tanuló és dolgozó szakemberekért is, a kettő nem élvez egyforma prioritást. A kormány felfogásában ugyanis, ami szellemi tőkeként hozzájárul a kínai gazdaság fejlődéséhez, az fontos, míg bármi más gyakorlatilag fölösleges (Li 2005: 78).

\section{ÖSSZEFOGLALÁS}

Kína kivándorlása hosszú időn keresztül meghatározó volt sok nyugati és délkelet-ázsiai ország számára, gondoljunk csak Szingapúr függetlenné válására, amiben a kínai lakosság szerepe meghatározó volt a 20. század közepén. Kína szemszögéből azonban évszázadokon át demográfiai és gazdasági veszteséget, továbbá nemzetbiztonsági kockázatot is jelentett az elvándorlás. Így volt ez a késői Csingtől egészen a közelmúltig, és a szabályozás leginkább tiltásokat és korlátokat jelentett; nem csoda, hogy a legfontosabb kivándorlási hullámok ugyan mindig különböző okok miatt, de a legkevésbé ellenőrzött déli tartományokból indultak. Ennek közvetlen hatásait ma is érzékelhetjük a beáramló külföldi tőke területi különbségeiben, a határokon átnyúló rokoni kapcsolatok politikai jelentőségén és számtalan más formában is.

A kivándorlás Kínából Mao halálával, illetve. az azt követő Teng Hsziao-ping által megvalósított reformokkal vett fordulatot az 1980-as évek elején. Ennek átütő erejü jogi intézményei az 1986-os új, A külföldiek ki- és belépéséről szóló törvény, illetve a személyi igazolvány bevezetése voltak. A kivándorlás terén tett engedmények az 1980-as években nagyrészt a szellemi tőke és az innováció beáramlásának közvetett eszközeiként szolgáltak. A kiutazást a diákok, a tudósok és a szakemberek számára lehetővé tévő politika azonban egy igen jelentős min- 
tázat megalkotásának is forrásává vált: mára meghatározó a magasan képzettek kivándorlása Kínából, és ez komoly veszteség az ország számára. A mai kínai regulatív politika azonban sokkal rugalmasabb, szemléletében a haszonszerzést kevésbé korlátozzák ideológiai elemek, éppen ezért már a kiutazást nem igyekszik keretek közé szorítani, feltételekkel terhelni, sőt a visszatérést is egyre kevésbé erőlteti a kormány. A mai célok között nem a demográfiai veszteség fékezése, hanem a szellemi és közvetlen gazdasági tőke beáramlása a meghatározó, ezt pedig nem feltétlenül a hazautazással, visszatelepüléssel kívánja elérni a Népköztársaság. 


\section{IRODALOM}

2007. évi II. törvény a harmadik országbeli állampolgárok beutazásáról és tartózkodásáról. 35/A. §.

Államadósság Kezelő Központ Zrt. (ÁKK) Állampapír forgalmazás. http://www.akk.hu/ hu/oldal/allampapir-forgalmazas. Letöltve: 2018. 07. 22.

Asian Development Bank Institute 2014: Labor Migration, Skills and Student Mobility in Asia. ADBI, Tokyo.

Bank of China and Hurun Research Institute 2011: Private Banking White Paper. Bank of China and Hurun Research Institute, Beijing.

Barabantseva, Elena 2005: The Party-State's Transnational Outreach: Overseas Chinese Policies of the PRC's Central Government. In Greater China Occasional Paper Series, no. 2. Institute of Chinese and Korean Studies, University of Tubingen.

Barabantseva, Elena 2012: Who Are "Overseas Chinese Ethnic Minorities"? China’s Search for Transnational Ethnic Unity. Modern China, 38(1), 78-109.

Bernstein, Thomas P. 2010: Introduction: The Complexities of Learning from the Soviet Union. In Bernstein, Thomas P. - Hua-yu Li (eds.): China learns from the Soviet Union, 1949-present. Lexington Books, Lanham. 1-27.

Brookings Institution 2014: Analysis of DHS Office of Immigration Statistics. In Singer, Audrey - Camille Galdes (eds.): Improving the EB-5 Investor Visa Program: International Financing for U.S. Regional Economic Development. Brookings Institution, Washington.

Brown, Judith M. - Rosemary Foot (eds.): 1994: Migration: the Asian Experience. Macmillan, London.

Brubaker, Rogers 2005: The 'Diaspora’ Diaspora. Ethnic and Racial Studies, 28(1), 1-19.

Canadian Citizenship \& Immigration Resource Center. Quebec Immigrant Entrepreneur. http://www.immigration.ca/en/quebec-business-immigration.html\#investor. Letöltve: 2018. 07. 11.

Charney, Michael W. - Brenda S. A. Yeoh - Tong Chee Klong (szerk.): 2003: Chinese Migrants Abroad. Cultural, Educational, and Social Dimensions of the Chinese Diaspora. World Scientific Publishing, Singapore.

Chen, Albert H. Y. 2011: The Law of Property and the evolving system of property rights in China. In Yu, Guanghua (ed.): The Development of the Chinese Legal System. Change and Challenges. Routledge, London. 81-112.

Chin, James K. 2003: Reducing Irregular Migration from China. International Migration, 41(3), 49-72.

Chin, Ko-Lin 1999: Smuggled Chinese: Clandestine Immigration to the United States. Temple University Press, Philadelphia.

Choi, Ching Yan 1975: Chinese Migration and Settlement in Australia. Sydney University Press, Sydney.

Christiansen, Flemming 2003: Chinatown, Europe: an exploration of overseas Chinese identity in the 1990s. RoutledgeCurzon, London.

CIA World Factbook. Country Comparison. Net Migration Rate. https://www.cia.gov/library/ publications/the-world-factbook/rankorder/2112rank.html\#ch. Letöltve: 2018. 07. 11. 
Citizenship and Immigration Canada 2012: Business Immigrants - Investors: Findings from the Longitudinal Immigration Database (IMDB). IMDB 2008 Research Series.

Clemens, Michael A. 2013: What Do We Know About Skilled Migration and Development? Migration Policy Institute. Policy Brief, 12(3), 1-12.

Cole, Michael 2013: Portugal Takes on St Kitts as the Next Chinese Immigration Destination. Mingtiandi, 21 April, 2013. http://www.mingtiandi.com/real-estate/outbound-investment/portugal-takes-on-st-kitts-as-the-next-chinese-immigration-destination/. Letöltve: 2018. 07. 11.

Cole, Michael 2014: Canada Slams Door on 45K Chinese Millionaires With End of Visa Program. Forbes, 13 February, 2014. https://www.forbes.com/sites/michaelcole/ 2014/02/13/canada-slams-door-on-45k-chinese-millionaires-with-end-of-visaprogram/\#3bfacc04642e. Letöltve: 2018. 07. 11.

Committee on Self-Funded Study Abroad Service, CEAIE. Services for Chinese Students Study Abroad. http://en.ceaie.edu.cn/agencies?columnid=39. Letöltve: 2018. 07. 13.

Commonwealth of Australia, Department of Immigration and Border Protection (DIBP) 2018: Significant Investor visa statistics. http://www.border.gov.au/about/reports-publications/research-statistics/statistics/work-in-australia/significant-investor-visa-statistics. Letöltve: 2018. 07. 11.

DIBP 2014: Australia's Migration Trends 2013-14. Emigration Trends and Policies in China: Movement of the Wealthy and Highly Skilled. Commonwealth of Australia, Canberra.

Docquier, Frédéric 2014: The brain drain from developing countries. IZA World of Labor, 2014: 31doi: 10.15185/izawol.31

Embassy of the People's Republic of China in the United States. Washington DC. Passport Law of the People's Republic of China. http://www.china-embassy.org/eng/ywzn/ Isyw/vpna/faq/t710009.htm. Letöltve: 2018. 07. 03.

Freedman, Amy L. 2000: Political Participation and Ethnic Minorities. Chinese Overseas in Malaysia, Indonesia, and the United States. Routledge, New York.

Government of Québec. Immigration rules and procedures. http://www.immigration-quebec.gouv.qc.ca/en/informations/rules-procedures.html. Letöltve: 2018. 07. 11.

Hautzinger Zoltán - Hegedűs Judit - Klenner Zoltán 2014: A migráció elmélete. Nemzeti Közszolgálati Egyetem, Budapest.

Hinton, William 2006: Through a Glass Darkly U.S. Views of the Chinese Revolution. Monthly Review Press, New York.

Hurun Research Institute 2013: The Chinese Millionaire Wealth Report 2013. Hurun Report, Shanghai.

ICEF Monitor 2016: A record number of Chinese students abroad in 2015 but growth is slowing. 6 Apr 2016. http://monitor.icef.com/2016/04/a-record-number-of-chinesestudents-abroad-in-2015-but-growth-is-slowing/. Letöltve: 2018. 07. 11.

Investor Visa Canada 2018. http://www.investorimmigrationcanada.com. Letöltve: 2018. 07. 11. Kenley, David L. 2003: New culture in a new world: the May Fourth Movement and the Chinesediaspora in Singapore, 1919-1932. Routledge, New York.

Koudela Pál 2017: A kínai diaszpóra. Polgári Szemle, 13(1-3), 370-384. DOI: 10.24307/ psz.2017.0931 
Kuah-Pearce, Khun Eng - Andrew P. Davidson (szerk.): 2008: At home in the Chinese diaspora: memories, identities and belongings. Palgrave Macmillan, New York.

Lever-Tracy, Constance - David, Ip - Noel, Tracy 1996: The Chinese Diaspora and Mainland China: An Emerging Economic Synergy. Macmillan Press, Houndmills.

Li, Cheng 2005: Coming home to teach: status and mobility of returnees in China's higher education. In Li, Cheng (ed.): Bridging Minds across the Pacific: U.S.-China Educational Exchanges, 1978-2003. Lexington, Lanham. 69-109.

Lim, Walter S. H. 2013: Narratives of Diaspora Representations of Asia in Chinese American Literature. Palgrave Macmillan, New York.

Lin, Mei 2010: Chinese Migrant Workers in Singapore: An Analysis Based on Interviews. International Journal of China Studies, 1(1), 194-215.

Liu, Baocun; Xiaolin Liu - Liaojian Qu 2013: Cross-Border Higher Education in China: Development, Challenges and Responses. Comparative Education Bulletin, 15(1), 13-24.

Liu, Geanghua 2014: Private employment agencies and labour dispatch in China. Working Paper. International Labor Organization, Geneva.

Liu, Guofu - Zejun Du 2014: The People's Republic of China Policy and Institutional Frameworks, National Report. INTERACT Research Report 2014/19. European University Institute Robert Schuman Centre for Advanced Studies.

Liu, Guofu 2006: The Right to Leave and Return and Chinese Migration Law. Martinus Nijhoff Publishers, Leiden.

Liu, Guofu 2009: Changing Chinese Migration Law: From Restrictionto Relaxation. International Migration \& Integration, 10(3), 311-333.

Liu, Guofu 2011: Chinese Immigration Law. Routledge, London.

Liu, Ping 2006: The Left-Wing Drama Movement in China and Its Relationship to Japan. Positions, 14(2), 449-466.

Liu, Xiaoguang; Qin Gou - Feng Lu 2015: Remedy or Poison: Impacts of China's Outward Direct Investment on Its Exports. China \& World Economy, 23(6), 100-120.

Liu, Yanbin 2008: Demographic Change and International Labor Mobility Implications for Business and Social Development in China. Working paper for Symposium Demographic Change and International Labor Mobility in the Asia Pacific Region, organized by Pacific Economic Cooperation Council.

Madokoro, Laura 2016: Elusive refuge: Chinese migrants in the Cold War. Cambridge, Harvard University Press.

Meisner, Maurice 1999: Mao's China and After. A History of the People's Republic. The Free Press, New York.

Miao, Lu - Wang, Huiyao 2017: International Migration of China. Status, Policy and Social Responses to the Globalization of Migration. Springer, Singapore.

Ministry of Commerce People's Republic of China. Regulations on Management of Foreign Labor Service Cooperation. June 13, 2012. http://english.mofcom.gov.cn/article/policyrelease/bbb/201209/20120908366677.shtml. Letöltve: 2016. 07. 04.

Ministry of Commerce, People's Republic of China. Brief Statistics on China's Foreign Labor Service Cooperation Overseas in 2015. http://english.mofcom.gov.cn/article/ statistic/foreigntradecooperation/201603/20160301273503.shtml. Letöltve: 2018. 07. 11. 
Ministry of Commerce, People's Republic of China. Brief Statistics on China's Foreign Labor Service Cooperation Overseas in 2017. http://english.mofcom.gov.cn/article/ statistic/foreigntradecooperation/201802/20180202715875.shtml. Letöltve: 2018. 07. 11.

Ministry of Foreign Affairs of the People's Republic of China. Treaty of Good-Neighborliness and Friendly Cooperation Between the People's Republic of China and the Russian Federation. http://www.fmprc.gov.cn/mfa_eng/wjdt_665385/2649_665393/ t15771.shtml. Letöltve: 2018. 07. 08.

Ministry of Land and Resources of the People's Republic of China. Land Administration Law of the People's Republic of China. http://www.npc.gov.cn/englishnpc/Law/200712/12/content_1383939.htm. Letöltve: 2018. 07. 08.

Nasolomampionona, Rakotonanahary Fanomezantsoa 2014: Profile of Chinese Outbound Tourists: Characteristics and Expenditures. American Journal of Tourism Management, 3(1), 17-31.

National Bureau of Statistics 2014: National Economic and Social Development Statistics Bulletin. Beijing, National Bureau of Statistics, 2014. www.stats.gov.cn/tjsj/ zxfb/201402/t20140224_514970.html. Letöltve: 2018. 07. 11.

Nyíri Pál 2010: Transznacionalitás és a közvetítő kisebbség-modell: kínai vállalkozók Magyarországon. In Feischmidt Margit (szerk.) Etnicitás. Különbségteremtő társadaIom. Budapest, Gondolat-MTA Kisebbségkutató Intézet. 141-151.

Office of the Historian, Bureau of Public Affairs United States Department of State. U.S.China Ambassadorial Talks, 1955-1970. https://history.state.gov/milestones/1953-1960/ china-talks. Letöltve: 2018. 07. 14.

Organisation for Economic Co-operation and Development (OECD) 2013: World Migration in Figures. Database on Immigrants in OECD and non-OECD Countries: DIOC.

Oyen, Meredith 2016: The Diplomacy of MigrationTransnational Lives and the Making of U.S.-Chinese Relations in the Cold War. Ithaca, Cornell University Press.

Park, Yoon Jung 2009: Chinese Migration in Africa. Occasional Paper No. 24. China in Africa Project. South African Institute of International Affairs, Braamfontein.

President of the People's Republic of China. 2007: Law of the People's Republic of China on the Control of the Exit and Entry of Citizens. http://www.npc.gov.cn/englishnpc/ Law/2007-12/13/content_1383959.htm. Letöltve: 2018. 07. 02.

President of the People's Republic of China. Law of the People's Republic of China on Control of the Entry and Exit of Aliens. http://www.china.org.cn/english/travel/40340. htm. Letöltve: 2018. 07. 02.

Rae, Ian -Witzel, Morgen 2008: The Overseas Chinese of South East Asia. History, Culture, Business. Palgrave Macmillan, Houndmills.

Reforms urged to attract overseas Chinese. Xinhua, 2012. március 11. http://www.china.org. cn/china/NPC_CPPCC_2012/2012-03/11/content_24865428.htm. Letöltve: 2018. 11. 21.

Rithmire, Meg E. 2015: Land Bargains and Chinese Capitalism: The Politics of Property Rights under Reform. Cambridge University Press, Cambridge.

Scott, James C. 2009: The Art of Not Being Governed: An Anarchist History of Upland Southeast Asia. New Haven, Yale University Press. 
Shi, Mary 1995: China. In Baehr, Peter; Hilde Hey; Jacqueline Smith - Theresa Swinehart (eds.): Human Right in Developing Countries 1994 Yearbook. Kluwer Law and Taxation Publishers, Deventer. 151-202.

Short, Philip 2001: Mao: A Life. Henry Holt and Company, New York.

Shu-Ching Chen, Jean 2008: China's 'Go Out’ Policy A One-Way Street. Forbes, 25 June, 2008. http://www.forbes.com/2008/06/25/cifa-zoomlion-construction-markets-equity-cx_jc_0625markets02.html. Letöltve: 2016. 07. 01.

Soler-Matutes, Jacint 2000: Privatisation and Local Governments in Mainland China: A Critical Assessment. Intereconomics, 35(3), 137-145.

St. Kitts \& Nevis. Citizenship by Investment. St Kitts \& Nevis Citizenship. http://stkitts-citizenship.com/. Letöltve: 2018. 07. 11.)

The State Council. The People's Republic of China: Exit and Entry Administration Law of the People's Republic of China. http://english.gov.cn/archive/laws_regulations/2014/09/22/content_281474988553532.htm. Letöltve: 2016. 07. 04.

Thunø, Mette - Pieke, Frank N. 2005: Institutionalizing Recent Rural Emigration from China to Europe: New Transnational Villges in Fujian. International Migration Review, 39(2), 485-514.

Tichenor, Daniel J. 2002: Dividing Lines: The Politics of Immigration Control in America. Princeton, Princeton University Press.

TRT World 2017: Pakistan and India join SCO security bloc. https://www.trtworld.com/ asia/pakistan-and-india-join-sco-security-bloc-7750. Letöltve: 2018. 07. 02.

U.S. Department of Homeland Security. U.S. Citizenship and Immigration Services. EB-5 Immigrant Investor Program. About the EB-5 Visa. https://www.uscis.gov/ working-united-states/permanent-workers/employment-based-immigration-fifthpreference-eb-5/about-eb-5-visa-classification. Letöltve: 2018. 07. 11.

U.S. Department of State, Bureau of Consular Affairs: Table V: Immigrant Visas Issued and Adjustments of Status Subject to Numerical Limitations, Fiscal Year 2014. In Report of the Visa Office, 2014. Washington, U.S. Department of State.

U.S. Department of State, Bureau of Consular Affairs: Table V: Immigrant Visas Issued and Adjustments of Status Subject to Numerical Limitations, Fiscal Year 2017. In Report of the Visa Office, 2017. Washington, U.S. Department of State.

U.S. Department of State, Historical Office. Congress. Senate. Committee on Foreign Relations. 1957: American foreign policy. 1950-1955 basic documents. Government Printing Office, Washington.

UK Spouse and Settlement Visa - Swift Immigration. https://www.swiftimmigration. co.uk/uk-spouse-and-settlement-visa/. Letöltve: 2018. 11. 21

United Nations (UN) 2015b: World Population Prospects: The 2015 Revision, Key Findings and Advance Tables. United Nations, New York.

United Nations (UN) 2017: Migrant Stock by Origin and Destination, 2017. United Nations, New York.

United Nations (UN), Department of Economic and Social Affairs, Population Division 2015a: Trends in International Migrant Stock: Migrants by Destination and Origin. United Nations database, POP/DB/MIG/Stock/Rev.2015 
Wang, Huiyao 2012: China's Competition for Global Talents: Strategy, Policy and Recommendations. Asia Pacific Foundation of Canada, Research Report.

Wichberg, Edgar 1994: The Chinese as Overseas Migrants in Brown. In Brown, Judith M. Rosemary Foot (eds): Migration: the Asian Experience. Macmillan, London. 12-27.

Wiedemann Tamás 2017: Végleges: húszezer bevándorló érkezett a kötvényprogrammal. Magyar Nemzet, 2017. december 7.

Wishnick, Elizabeth 2005: Migration and economic security: Chinese labour migrants in the Russian Far East. In Akaha, Tsuneo - Anna Vassilieva (eds.): Crossing national borders: Humanmigration issues in Northeast Asia. United Nations University Press, Tokyo. 68-93.

Xiang, Biao 2003: Emigration from China: A Sending Country Perspective. International Migration, 41(3), 21-48.

Xiang, Biao 2006: Emigration from China: a sending country perspective. In Liu, Hong (ed.): The Chinese Overseas, Volume IV. Homeland Ties and Agencies of Interaction. Routledge, New York. 352-379.

Xiang, Biao 2012: Predatory Princes and Princely Peddlers: The State and International Labour Migration Intermediaries in China. Pacific Affairs, 85(1), 47-68.

Xiang, Biao 2014: The Upward Concentration of Chinese Emigration and the Rise of China. Compas, 23 August 2014. https://www.compas.ox.ac.uk/2014/the-upward-concentration-of-chinese-emigration-and-the-rise-of-china/. Letöltve: 2016. 07. 01.

Xiang, Biao 2015: The Rise of China, changing patterns of out-migration and identity implications. In Iredale, Robyn R. - Fei Guo (eds.): Handbook of Chinese Migration: Identity and Wellbeing. Edward Elgar, Cheltenham. 278-297.

Xiang, Biao 2016: Emigration Trends and Policies in China Movement of the Wealthy and Highly Skilled. Migration Policy Institute, New York.

Yang, Zan - Jie Chen 2014: Housing Affordability and Housing Policy in Urban China. Springer, Heidelberg.

Yong, Ching-Fatt 2014: Tan Kah-kee. The Making of an Overseas Chinese Legend. World Scientific Publishing, Singapore.

Young, Ian 2014: Canada scraps millionaire visa scheme, 'dumps 46,000 Chinese applications'. South China Morning Post, 12 February, 2014. http://www.scmp.com/news/ world/article/1426368/canada-scraps-millionaire-visa-scheme-dumps-46000-chinese-applications. Letöltve: 2018. 07. 11.

Zhu, Guobin 2012: The composite state of China under "One Country, Multiple Systems": Theoretical construction and methodological considerations. International Journal of Constitutional Law, 10(1), 272-297.

者徐哲 (Xu Zhe) 2019: 城市移民工低收 中共政府对抗贫困面临挑战 (A városi migráns munkavállalók jövedelmei alacsonyak, a kínai kormány kihívásokkal szembesül a szegénység elleni küzdelemben.) NTD. Január 14. http://ca.ntdtv.com/xtr/gb/2017/10/15/ a1346844.html Letöltve: 2019. 01. 14.

非洲裔人员聚集事件调查：数万人非法居留广州 (Nyomozás az afrikai csoportosulás ügyében: tízezrek tartózkodnak illegálisan Kantonban. 新华网 (XinhuaNet) 2009 július 20. http://news.sina.com.cn/c/sd/2009-07-20/095918257011.shtml Letöltve: 2019. 01. 14. 


\section{EMIGRATION AND ITS REGULATION IN CHINA}

\section{ABSTRACT}

Since the eighties China opened its doors and made possible for a narrower group of the population to leave the country legally. Emigration then was under tight control and served economic purposes. The regulation of outward migration was characterized by restrictions in China since the period of the Qing dynasty. In the last two decades, however, less and less formal elements are limiting citizens' exit and staying abroad, and the leadership is increasingly resilient about the economic benefits of emigrants. Today Chinese governments keep in mind not only the import of the human capital and direct foreign investments but also try to develop a global network. Nevertheless, emigration from China is still modest and characterized rather by high status groups. Increase in emigration is determined by the growing role of investor and student groups. Causes can be found partly in the strengthening of the economy, partly in the restrictions of receiving countries. Student emigration begun with the Open Door Policy and the government supported the accumulation of human capital then. Foreign degrees are extremely valuable in China up today, despite the development of higher education in principle solved the replenishment. However, a significant part of those emigrated to study does not return to China even today. The emigration of unskilled or lowskilled physical workers is tightly controlled by the governments, its direction and conditions are determined by the changes in Chinese foreign investments. At the same time, significant liberalization has also taken place in this area. 